\title{
Freedom and Determinism in Spinoza
}

JOHN M. RUSSELL

Indiana Central University

Spinoza's unrelenting emphasis on determinism and necessity seems, at first glance, incompatible with his espousal of human freedom. In what follows, I explicate Spinoza's meaning of the term "freedom" and argue that his use of the term is compatible with his theses of determinism and necessity. I conclude by noting some problems that Spinoza's determinism poses for his moral theory.

\section{Spinoza's "Denial" of Freedom}

Spinoza does reject some meanings of the term freedom. He repudiates the idea of "free choice." (By "free choice" I mean the possibility that a man could have chosen to act other than he actually did.) He further dismisses any account of "will" or "desire" that would support a credible account of free choice.

For Spinoza, nature admits of no contingency, caprice, or indeterminateness. In fact, man's very idea of free choice is the illusory result of inadeguate knowledge. "[M]en believe themselves to be free," he writes, "simply because they are conscious of their actions, and unconscious of the causes whereby those actions are determined." Man is limited by the confused perception that characterizes inadequate knowledge and, hence, delusively ascribes the adjective "free" to an alleged phenomenon of "choice." According to Spinoza, humans fail to recognize that acts of choice are caused and subsequently imagine "themselves free inasmuch as they are conscious of (their) volitions and desires," but they "never even dream, in their ignorance, of the causes which have disposed them to wish and desire." 2

Spinoza disagrees with those who assert that "human actions depend on the will," since "this is a mere phrase without any idea to correspond thereto." 3 Much like the intellect, the will is merely "a particular mode of thinking." Whether the will is conceived as finite or infinite, it too "requires a cause by which it should be conditioned to exist and act." Moreover, the will is related to God because "it must be cond1tioned by God (Prop. xxix) to exist and act in a particular manner." Explaining human action in terms of 
the will illustrates our ignorance; sufficient accounts of human action derive only from our having clear and adequate ideas of what causes behavior.

Analogously, Spinoza rejectes the notion of "decision" as representing an adequate explanation of "fiee choice." clearly, "a mental decision and a bodily appetite, or determined state, are simultaneous, or rather, are one and the same thing... . "c A decision is not free (i.e., a decision cannot be the cause of itself). External causes, then, constrain decisions as well.

Spinoza flatly affirms that "everything proceeds from a sort of necessity, and with the utmost perfection":?

Nothing in the universe is contingent, but all things are conditioned to exist and operate in a particular manner by the necessity of divine nature."

Men are not free in the fictitious sense that they imagine; ignorance--inadequate knowledge--is the source of this false meaning of freedom that spinoza rejects. Nothing in nature 18 indeterminate or uncaused, as Spinoza remarked in a letter to Boxel: "the world [is] a necessary effect of divine nature," thus he "utterly [denies that] the world has been made by chance." With respect to necessity and human choice, stuart Hampshire aptly concludes that

Any statement of the kind "an alternative action was possible" or "he could have done otherwise," is necessarily the sign of the incompleteness of our scientific knowledge or an expression of our present state of ignorance... . . 10

In conclusion, then, human choices are neither uncaused nor arbitrary; that choices are capricious is, for Spinoza, chimerical--an idea born out of ignorance.

Necessity applies to "will" and "decision." Will

is not a free cause, "only a necessary or constrained cause." 11 Will is externally caused and in no way can it adeguately support the idea of "free choice"; the will is determined to exist and act only by God. Thus, Spinoza clearly opposes any conception of "freedom" as tantamount to being uncaused or indeterminate. Rather, causes determine the will and, hence, human behavior can be considered neither capricious nor accidental. Correspondingly, since "decision" is simultaneous with a determined state, it is not a free cause. So decision also fails to sufficiently account for the idea of "free choice."

In conclusion, then, Spinoza allows for no "free choice"; the scope of necessity is universal. Necessity precludes the possibility of "free choice," whether 
conceived under the rubric of "will" or "decision." "Things could not have been brought into being by God in any manner or in an order different from that which in fact has obtained."12 Hence, man could not have acted other than he did; no alternative choice and action were even possible:

Each so called "act of choice" in the matter is in reality a necessarily determined assertion or denial . . . The "volitio," or "mentis derretum," is thus--like any ideal or extended event-absolutely determined and necessary."

God, Spinoza's all-inclusive substance (Deus sive Natura). comprises the universe, and each "mental" or "physical" event of experience follows necessarily from this one substance.

\section{Spinoza and Cause}

Spinoza rejects the notion of final causes in nature; "everything in nature precedes from a sort of necessity and with the utmost perfection." "The notion of final cause "does away with the perfection of God: for if God acts for an object, he necessarily desires something which he lacks." 25 But this idea is absurd, for it contradicts the very nature of God. Accordingly, Spinoza states "that nature has no goal in view, and that final causes are mere human figments." Is When men strive to illustrate "that nature does nothing in vain..." they "seem to have demonstrated that nature, the gods, and men are all mad together."1" But what does spinoza affirm about types of causes?

Spinoza accepts the idea of efficient causality. and he attributes it to the deity. God is "the sole free cause." "lod, "absolutely the first cause." encompasses all that is. Everything that is, "is in God, and without God nothing can be, or be conceived."20 "Erom the necessity of divine nature must follow an infinite number of things in infinite ways... "21 He "is the efficient cause of all that can follow within the sphere of infinite intellect."12 This efficient causality applies "not only to the existence of things, but also of their essence."23 Things depend on God for their "coming into existence" and their "continuing in existence" or being. "

Does Spinoza regard the notions of formal and material causality as equally crucial to the description of God? His answer to this question is negative. Efficient causality best characterizes God's activity. Spinoza rejected Aristotle's distinction of matter and form, modifying them with the substantival attributes of thought and extension. Accordingly, as Wolfson notes, the Aristotelean "designation of causes as material and formal likewise disappears"; Spinoza sub- 
sumes formal causality under efficient causality, hence the efficient cause most aptly describes God's nature. ${ }^{25}$

Efficient causality applies to both the physical and mental modes of experience. God, the efficient cause of that which occurs within the sphere of infinite intellect, can surely be regarded as a thinking thing. Thus it is apparent that "the actual being of ideas owns God as its cause," and "the ideas of both the attributes of God and particular things" have, as their efficient cause, God himself, "insofar as he is a thinking thing." 26 Perhaps an example will help to clarify this applicability.

Consider the activity of building a house. Spinoza states that a cause referred to as final is "nothing else but human desire..." For instance, "when we say that to be inhabited is the final cause of this or that house, we mean nothing more than that a man . . . had a desire to build a house."27 The specific desire, that of "the being inhabited", is really the efficient cause."2" An amplification of the term "desire" will illumine how efficient causality relates to the mental mode.

An appetite is an endeavor "when referred to mind and body in conjunction." 29 Desire is defined as "appetite with consciousness thereof." "Desire, then, is an efficient cause and is an appetite with consiousness appended. Consciousness clearly concerns the mental mode of experience: thus efficient causality applies to the mental mode of experience. Spinoza's example, the activity of building a house, illustrates that efficient causality pertains to both the physical and mental aspects of experience.

\section{Man's Conatus}

Spinoza states that "everything insofar as it is in itself, endeavors to persist in its own being." 3 Conatus, then, is the self-preserving effort of particular things. In this endeavor, a thing resists that which "could take away 1 ts existence." 32 In short, conatus is "the actual essence of the thing in question." "The tendency toward self-preservation is present in and comprises the very definition of particular things, for spinoza.

Generally speaking, conatus is also a theory that concerns the interaction of things. Note that a particular thing is, for Spinoza, that which has a conditioned, finite existence. Under this endeavor, "each particular thing within the universe, by the eternal necessity of the nature of the universe as a whole of what it is a part, strives to maintain its existence. " " Nature, then, is comprised of individual modes that constantly endeavor to maintain themselves 
and, in so doing, interact with different particular modes that affect them.

Conatus applies to the attributes of both extension and thought. An obvious parallel can here be observed: continuance or resistance in movement is the expression of the body's conatus. Continuance in thought represents the mind's conatus. Finally, the mind strives to affirm the existence of the body, since any idea negating the body's existence "cannot be postualted in our mind, but is contrary thereto." 's

When conatus refers to the mind alone, the endeavor is called "will." "When referred to the mind and body in conjunction, it [conatus] is called appetite." 27 Spinoza's point is that desire and appetite are equivalent terms. A subtle difference remains, though. When we are cognizant of our appetites, desire prevails. "Man, however, is aware of his appetites and urges (though not of their causes) and so, particularly when we have this self-awareness in mind, we may speak of desire."

\section{Man's Conatus and God}

Man is an individual thing and "individual things are nothing but the modifications of attributes of God, or modes by which the attributes of God are fixed and expressed in a determinate manner."39 Spinoza further reasons that the essence of both the human body and mind "must be conceived through the very essence of God."A Inasmuch as individual things depend on and participate in Divine substance, they are, in a restricted sense, infinite and eternal. God's causality unfolds through eternal infinite modes and its effects are likewise eternal and infinite. The idea of "... every particular thing actually existing, necessarily involves the eternal and infinite essence of cod." Hence a particular being, like man, participates to a degree, in eternity: "Now in a sense particular things are eternal--i.e.. 'vi causa cui inhaerent. "'2 To the extent that individual things participate in the one Divine substance, they are eternal."

Man's conatus has as its source of power, the power of God. God is the cause of the being of things or of "their continuing in existence." "Thus, "the force by which each particular thing persevers in existing follows from the eternal necessity of God's nature."is In conclusion, then, each individual's endeavor toward self-preservation or conatus originates from the necessity and eternity of God's nature.

Interrelation of Cause and Conatus: Assertion of Human Freedom

Spinoza's typology of cause includes those that are "inadequate" and "adequate." Conatus should be placed 
within the context of this distinction. Once this objective has been accomplished, an affirmation of human freedom can be explained.

An "inadequate" or partial cause is a "cause through which, by itself, its effect cannot be understood." Men are "passive" when "something takes place within us, or follows from our nature externally. we being only the partial cause." "'

An "adequate cause" is "a cause through which its effect can clearly and distinctly be conceived." "s It exists "when through our nature something takes place within us or externally to us, which can through our nature alone be clearly and distinctly understood." Men can be said to act or be active "when anything takes place. . . whereof we are the adequate cause."

Each individual thing strives to maintain itself and this follows from the nature of God, according to Spinoza: "|T|he force by which each particular thing perseveres in existing follows from the necessity of God's nature."'s Clearly the force of conatus is necessary by virtue of the essence of God; conatus is not externally constrained or caused. This fact is basic to our understanding Spinoza's conception of human freedom.

\section{Man in Bondage or Constraint}

That which follows from external causes, where man is passive, is constrained rather than free. Spinoza states that constraint occurs when something "is determined by something external to itself to a fixed and definite method of existence or action."1s one can be bound, then, when constrained by the action of another individual. Man is but a partial cause, concerning that which follows from his nature externally. Hence bondage is, for Spinoza, equivalent to inadequate causality and represents the absence of freedom.

\section{Man as Active and Eree}

Those acts which follow from adequate causes are neither compelled nor constrained from without. When man is the adequate causal agent of his actions, then he is free. Individuals are "active" according to Spinoza, when they are the authors (causes) of their own actions. To the extent that an individual is active--the adequate cause of his own actions--that individual is free. Here we see that freedom, activity, and causal agency are compatible terms.

How can we free ourselves from the constraint of passion and bondage? The determination that characterizes reason or adequate knowledge can release us from the yoke of passion. More narrowly, we can modify and transform confused ideas and passions (like a particular emotion) through self-conscious reflection. 
Spinoza states that "an emotion, which is a passion, ceases to be a passion, as soon as we form a clear and distinct idea thereof." calls a passion is also a confused idea. When "we form a clear and distinct idea of a given emotion... . the emotion will cease [in effect] to be a passion." Accordingly, we attain freedom by forming clear and distinct ideas (adequate knowledge) about passions. Note that these clear and distinct ideas are causes-instances of cognitive or mental determination. Generally, then, we "determine solely by the knowledge of the mind, the remedies against" confused ideas or emotions."s

\section{Man's Conatus, God and Ereedom}

We recall that, for Spinoza, God alone is the sole free cause. Moreover, man's conatus derives from the "eternal necessity of God's nature"; in short, man's conatus is really God's conatus. Any human act that follows from conatus is not constrained or compelled from without. Rather, it is the product of adequate causality. To the degree that man's acts derive from conatus, he can be said to be "free."

\section{Exposition of Freedom}

Man's freedom, in marked contrast to God's, is not perfect (complete). Man's freedom is limited. Man is free when he is seen in his proper relation to God. Human freedom cannot exist when man is concelved as separate from God and the infinity of the whole modal system. Human freedom is an extension--a manifestation--of the power of God. In this context, man's freedom is neither absolute nor constant. Rather, an individual's being active or free varies in degree. Striving to maintain one's self (conatus) can be hindered or limited by opposing the conatus of other individuals. In other words, individual things interact and each thing's conatus resists that of another in the process of interaction. However, the opposing conatus of each particular thing does not constitute external constraint per se, as seen in proper relation to God.

\section{The Compatibility of Freedom and Determinism}

In what sense does Spinoza employ the term "free"? clearly Spinoza rejects an idea of "free" as meaning uncaused or indeterminate. The matter of a "free" act. whether caused or uncaused, is irrelevant. "Ereedom" is consistently employed by him within the context of a thorough-going determinism. But determinism must be contrasted with compulsion or constraint; these terms, in Spinoza, are not synonymous. 
Freedom and determinism are comparable terms, but freedom contrasts with bondage. The free agent acts in a determinate manner, but without being constrained or compelled. All acts, both those which are free and those which are bound, are caused, determined. But the crucial difference lies in the type of determination proper to each. Free actions represent adequate types of determination; bound acts represent passive instances of determination.

If freedom is seen as a determined act that is devoid of compulision or external constraint, then freedom and determinism are indeed compatible terms. Acts can thus be free, yet determined. But freedom as Spinoza intended the term, is not compatible with bondage, passivity, or compulsion.

\section{Critique}

What type of determinism characterizes Spinoza's use of freedom? A free person is self-determining in that he actively causes his behavior by forming adequate knowledge of passions. Adequate knowledge-having clear and distinct 1deas--represents selfdirecting, rational determination that frees one from bondage or servitude. In his view of freedom, Spinoza also denies that an individual could have chosen to act in any way other than he did." This denial creates some difficulties for Spinoza's moral theory.

Spinoza's unrelenting determinism obviates a normative ethic. A person's behavior derives from two types of determination: either behavior is self-caused through adequate knowledge or behavior is externally caused (constrained) by passion. As William Frankena points out, a central goal of normative ethics "is to guide $u s$ in our capacity as agents trying to decide what we should do in this case and in that." Spinoza's metaphysical determiniam, however, eliminates the prescribing of moral "shoulds" or "oughts," since, whether behavior is self-caused or externaliy caused, the person could not have acted other than he did. Self-causation and external causation are not determinants of choice.

The matter does not end here though. What type of moral theory are we left with, if a moral agent can perform only that action that he ipso facto performed? A prescriptive ethic, wherein moral agents are exhorted to realize ethical ideals, seems irreconciliable with Spinoza's determinism. At best, then, Spinoza is left with a descriptive ethic, wherein we observe, analyze, and describe the moral conduct of agents. Hence Spinoza's determinism truncates a traditionaliy important objective of moral theory. In a letter to spinoza (Epistle LXXVII) oldenburg warns spinoza about this very implication of "universal necessity": [God's] inflexible fate, and . . irresistible power compel us 
to act in a given manner, nor can we possibly act otherwise.

Consider another problem that emerges from Spinoza's determinism. The idea of moral responsibility becomes rather untenable, if antecendnt causes necessarily determine subsequent events. Again, Oldenburg brought this problem to spinoza's attention: the doctrine of fatalistic necessity renders "[moral] rewards and punishments... Ineffectual .... For if we men are, in all of actions, moral as well as natural, under the power of God, like clay in the hands of the potter, with what face can any of us be accused of doing this or that, seeing that it was impossible [emphasis added] to do otherwise."ss oldenburg concludes his argument by saying that "Everyone may plead, 'Thy power cannot be escaped from, 0 God; therefore, since I could not act otherwise, I may justly be excused." "6o Spinozistic determinism precludes moral blame and praise.

Einally, Spinoza's problem intensifies when he speaks of ideals that moral agents ought to seek:

- . [E]very man should [emphasis added] love himself, should see that which is useful to him - . and should, each for himself, endeavor as far as he can to preserve his own being."

Spinoza's advocacy of metaphysical determinism conflicts with his prescribing morals shoulds; consider the problematic alternatives this poses:

I. 1. Spinoza cannot both advocate metaphysical determinism and prescribe moral shoulds.

2. Spinoza advocates metaphysical determinism.

3. Thus Spinoza cannot prescribe moral shoulds.

II. 1. Spinoza cannot both advocate metaphysical determinism and prescribe moral shoulds.

2. Spinoza prescribes moral shoulds.

3. Thus Spinoza cannot advocate metaphysical determinism.

Spinoza cannot have it both ways. But he does advocate metaphysical determinism, and he prescribes moral shoulds. Accordingly, Spinoza's denying that an individual could have chosen to act other than he in fact acted, renders his moral theory problematic. 


\section{NOTES}

'Spinoza, Benedict de, The Ethics, trans. R. H. M. Elwes (Washington: M. Walter Dunne, Publisher, 1901), Eth. III: 2 Note.

2Ibid., Eth. I App.

'Ibid., Eth. II: 35 Note

Ibid., Eth. I : 32 Proof

'Spinoza, Eth. I: 32 Cor. 2.

Ibid., Eth. III: 2 Note.

'Ibid., Eth. I App.

'Ibid., Eth. I: 29.

'Spinoza, Epistle Lvili (Spinoza to Hugo Boxel).

"Hampshire, stuart, Spinoza (London: Farber and Earber, mamil), p. 113.

"Spinoza, Eth., I: 33 Proof.

12 Ibid., Eth. I: 32 Proof.

"Joachim, Harold H., A Study of the Ethics of Spinoza, (Oxford: The Clarendon Press, 1901), p. 197.

"Spinoza, Eth. I App.

15 Ibid.

16 Ibld.

II Ibid.

"Ibid., Eth. I: 17 Cor. 2.

"Ibid., Eth. I: 16 Cor. 3.

2"Ibid.. Eth. I: 15.

21 Ibid., Eth. I : 16.

${ }^{22}$ Ibid., Eth. I: 16 cor. 1 .

23Ibid., Eth., I: 25.

2"Ibid., Eth., I: 24. 
"Cf. H. A. Wolfson's The Philosophy of Spinoza. vol. 1, pp. 302-3; 422 .

"Ibid., Eth. II: 5 .

'Ibid., Eth. IV Preface.

2 Ibid.

"Ibid., Eth. III: 9 Note.

30 Ibid.

'Ibid., Eth. III: 6.

32 Ibid., Eth. III: 6 Note.

"Ibid., Eth. III: 7 .

"Hampshire, Spinoza, pp. 92-93.

"Ibid., Eth. III: 10 .

"Ibid., Eth. III: 9 Note.

37 Ibid.

"Harris, Errol E., Salvation Erom Despair: A Reappraisal of Spinoza's Philosophy (The Hague: Martinus Nijhoff, 1973), p. 113 .

"Spinoza, Eth. I: 25 Cor.

"Ibid., Cf. Eth. V: 22 Proof and 23 Proof.

4'spinoza, Eth. II: 45.

'2Joachim, A Study, p. 76 .

"Spinoza, Eth. I I 45 Note.

"Spinoza, Eth. I: 24 Cor.

"Ibid., Eth. II: 45 Note.

"Ibid. Eth. III Def. 1.

"Ibid., Eth. III Def. 2.

"Ibid., Eth. III Def. 1 .

"Ibid., Eth. I I Def. 2 .

*Ibid. 
"Ibld., Eth. II: 45 Note.

"2Ibid., Eth. I Def. 7 .

"Ibid., Eth. V: III.

"Ibid., Eth. V: III Proof.

"Ibid., Eth. V: Preface.

"Cf. Spinoza, Eth. I: 29 and 32 Proof; Hampshire, op. cit., p. 113, and G. H. R. Parkinson, "On the Power and Freedom of Man," in Essays in Interpretation, eds. Maurice Mandelbaum and Eugene Freeman (La Salle, IL: Open Court, 1975), p. 22.

'Frankena, William E., Ethics 2nd ed. (Englewood Cliffs, NJ: Prentice Hall, Inc., 1973), p. 12 .

"Oldenburg, Epistle LXXVII.

"Ibld.

"Ibia.

'Spinoza, Eth. IV: 18 Note. 